\title{
Superovulation, fertilization and in vitro embryo development in mice after administration of an inhibin-neutralizing antiserum
}

\author{
H. Wang ${ }^{1,2}$, C. B. Herath ${ }^{1}$, G. Xia ${ }^{2}$, G. Watanabe ${ }^{1,3}$ \\ and K. Taya ${ }^{1,3 *}$ \\ ${ }^{1}$ Laboratory of Veterinary Physiology, Tokyo University of Agriculture and Technology, \\ Tokyo 183-8509, Japan; ${ }^{2}$ College of Biological Sciences, China Agricultural University, \\ Beijing 100094, China; and ${ }^{3}$ Department of Basic Veterinary Science, The United Graduate \\ School of Veterinary Science, Gifu University, Gifu 501-1193, Japan
}

The present study was conducted to investigate the effect of immunoneutralization against endogenous inhibin on oocyte and embryo production in adult and immature mice. At 12:00 $\mathrm{h}$ on day 2 of oestrus (day 1 of dioestrus), a single i.p. injection of inhibin antiserum $(50,100,200$ or $400 \mu \mathrm{l}$ per animal) or equine chorionic gonadotrophin (eCG; 10 or 20 iu per animal) or control goat serum $(100 \mu \mathrm{l}$ per animal) was administered to adult female mice. After $48 \mathrm{~h}$, the mice in each of the three groups were given a single i.p. injection of hCG (10 iu per animal). At $42 \mathrm{~h}$ after hCG injection, ova were collected from oviducts and cultured in KSOM solution. Treatments with both inhibin antiserum-hCG and eCG-hCG induced superovulation in all the animals tested. The number of oocytes in animals treated with inhibin antiserum was significantly higher $(P<0.05)$ compared with the control group, and the number of oocytes ovulated in animals treated with 200 or $400 \mu \mathrm{l}$ inhibin antiserum was significantly $(P<0.05)$ higher than that in animals treated with 10 or 20 iu eCG. The superovulated oocytes that were fertilized normally in vivo were able to form blastocysts in vitro. The rate of blastocyst development for animals treated with 50-200 $\mu$ l inhibin antiserum was significantly $(P<0.05)$ higher than that of the eCG-treated animals. Irrespective of the day of the oestrous cycle, $200 \mu$ linhibin antiserum administered at 12:00 $\mathrm{h}$ on each of 4 days induced superovulation in all the animals tested. The rates of oocyte and embryo production by these animals were significantly $(P<0.05)$ higher than in the control groups. Furthermore, administration of inhibin antiserum at doses of $50,100,200$ or $400 \mu \mathrm{l}$ produced similar results in 26 day-old immature mice. These results indicate that passive immunoneutralization of endogenous inhibin $\alpha$-subunit induces superovulation in immature and adult mice. The superovulated oocytes obtained by administration of inhibin antiserum have normal embryonic developmental competence. Thus, it is concluded that this inhibin antiserum method is a new practical alternative for induction of superovulation in mice instead of the more commonly used eCG-hCG protocol.

\section{Introduction}

Advanced reproductive techniques enable greater numbers of oocytes or embryos of high quality to be used to conduct much needed research into basic reproduction. Mice are used widely in the laboratory, especially to produce transgenic animals and also in embryo assay quality control tests for human in vitro fertilization (IVF) programmes (Scott et al., 1993). In most studies, the use of a combination of equine chorionic gonadotrophin (eCG) and hCG has been the most common method to induce superovulation in mice. This method yields a relatively large number of oocytes and embryos. However, a disadvantage of these protocols is the long half-life of eCG, which interferes with normal fertilization and embryo development (Fraser, 1977; Sato and Marrs, 1986; Edgar et al., 1987; Lehtonen and

*Correspondence

Email: taya@cc.tuat.ac.jp
Kankondi, 1987; Fossum et al., 1989; Ertzeid et al., 1993). It is increasingly accepted that oocyte and embryo quality may be affected by hyperstimulation with exogenous gonadotrophins (Legge and Sellens, 1994; Ma et al., 1997). Thus, it is necessary to establish an alternative simple method for induction of superovulation in mice to overcome these problems.

Inhibin is an essential hormone in the regulation of $\mathrm{FSH}$ secretion in various mammals (de Jong, 1988). In previous studies, a negative relationship between plasma concentrations of FSH and inhibin has been established in several mammalian species (Taya, 1993; Taya and Watanabe, 1999). FSH is one of the important endocrine hormones in the regulation of ovarian folliculogenesis. Multiple ovulations have been induced successfully by passive immunization against endogenous inhibin in several species such as hamsters (Kishi et al., 1996), rats (Rivier and Vale, 1989), guinea-pigs (Shi et al., 2000), cows (Akagi et al., 1997) and mares (Nambo et al., 1998). Thus, these 
initial results indicated that immunization of animals against endogenous inhibin, to induce superovulation through increased endogenous FSH secretion, is an alternative method to the current exogenous gonadotrophin protocols for the production of valuable embryos for use in IVF.

The aim of the present study was to develop a practical superovulation protocol in immature and adult mice by immunoneutralization of endogenous inhibin. Furthermore, in vitro development of preimplantation embryos was evaluated.

\section{Materials and Methods}

\section{Animals}

Immature (26-day-old) and adult (3-month-old) female mice of the ddY strain (Sankyo Experimental Animal Supply Co., Tokyo) were used. The mice were housed in metal cages and maintained in a room with controlled illumination (14 h light:10 h dark, lights on at 05:00 h) and temperature $\left(22-24^{\circ} \mathrm{C}\right)$, with free access to commercial pellets and tap water available ad libitum. The mice were checked daily for 4 day oestrous cyclicity by examination of vaginal smears. The day of ovulation, as judged by the presence of cornified cells in the vaginal smear, was designated day 1 of the oestrous cycle. All procedures were carried out in accordance with the guidelines established by the Department of Veterinary Medicine, Tokyo University of Agriculture and Technology, for use of laboratory animals.

\section{Preparation of inhibin $\alpha$-subunit antiserum}

The inhibin $\alpha$-subunit antiserum was obtained from a castrated goat immunized against [Tyr30]-porcine inhibin$\alpha(1-30)-\mathrm{NH}_{2}$ conjugated to rabbit serum albumin (kindly provided by N. Ling, Neurocrine Biosciences Inc., San Diego, CA). The conjugate (3.6 mg) was dissolved in $1 \mathrm{ml}$ saline and mixed with an equal volume of Freund's complete adjuvant. A castrated goat was given $2 \mathrm{ml}$ of the suspension (including $3.6 \mathrm{mg}$ of the conjugate) s.c. at each immunization. First, second and third immunizations were performed at 2 week intervals and, thereafter, monthly. Blood samples were obtained 2 weeks after each injection. The sera were collected and examined for inhibin antiserum titre, and titres of the antisera were checked in the following way. The antisera were diluted with 0.05 mol PBS I-1 ( $\mathrm{pH}$ 7.4) containing 1\% (w/v) BSA, and the diluted samples were incubated with 5000 c.p.m. [ $\left.{ }^{125} \mathrm{I}\right]$-labelled bovine $32 \mathrm{kDa}$ inhibin $\left(325 \mathrm{Ci} \mathrm{mmol}^{-1}\right)$ at $4^{\circ} \mathrm{C}$ for $24 \mathrm{~h}$ in a total volume of $200 \mu \mathrm{l}$. Bound radioligands were separated by adding $100 \mu \mathrm{l}$ of $1 \%(\mathrm{w} / \mathrm{v})$ bovine gamma globulin in PBS and $500 \mu \mathrm{l}$ of $25 \%(\mathrm{w} / \mathrm{v})$ polyethylene glycol in PBS, and agitating the mixture for $3 \mathrm{~min}$. After centrifugation at $1700 \mathrm{~g}$ at $4^{\circ} \mathrm{C}$ for $30 \mathrm{~min}$, the radioactivity of the precipitate was counted in a gamma counter. The serum used in the present experiment had a titre of $1: 1 \times 10^{6}$ as defined by final dilution of the antiserum required to bind $50 \%$ of added [125] -labelled bovine $32 \mathrm{kDa}$ inhibin. The in vivo efficiency of the antiserum was ensured by an increase in plasma concentrations of FSH after an i.v. injection of six doses (6.25-200.00 $\mu \mathrm{l})$ of the antiserum at 11:00 h on day 1 and day 2 of dioestrus. A dose-related increase in the basal secretion of $\mathrm{FSH}$ was observed at $24 \mathrm{~h}$ after the injection, and the maximum response was noted when $100 \mu$ l of the antiserum was injected. The capacity of the antiserum to neutralize the inhibin bioactivity of rat inhibin (ovarian homogenate) was also examined in vitro using a dispersed anterior pituitary cell bioassay system. The secretion of FSH from cultured rat anterior pituitary cells was suppressed in a dose-dependent manner by rat ovarian homogenate, and the maximum suppression of the ovarian homogenate could be reversed by addition of increasing dosages of the antiserum. Human transforming growth factor $\beta$ (TGF- $\beta$ ) and activin showed no crossreactivity with the inhibin antiserum. Control serum was obtained from a castrated goat immunized against BSA.

\section{Experiment 1: effect of different doses of inhibin} antiserum administered on day 2 of the oestrous cycle on oocyte production, fertilization and embryo development

Female adult mice were primed at 12:00 h on day 2 of the oestrous cycle (day 1 of dioestrus) with a single i.p. injection of different doses of inhibin antiserum (50, 100, 200 or $400 \mu \mathrm{l}$ per animal) or eCG (10 or 20 iu per animal) (Sankyo Zoki Co. Ltd, Tokyo) or control goat serum (100 $\mu \mathrm{l}$ per animal). After $48 \mathrm{~h}$ (day 4 of the oestrous cycle), the mice were given an injection of hCG (10 iu per animal) (Sankyo Zoki). The individual female mice were mated with a 3-month-old fertile male mouse of the $d d Y$ strain immediately after hCG administration. At $42 \mathrm{~h}$ after the hCG injection (day 2 after mating), five animals from each group were killed by decapitation and the oviducts were incised and separated for collection of embryos.

\section{Experiment 2: effect of a single injection of $200 \mu \mathrm{l}$} inhibin antiserum administered on each of 4 days of the oestrous cycle on oocyte production, fertilization and embryo development

A dose of $200 \mu \mathrm{l}$ inhibin antiserum administered at 12:00 h on day 2 of the oestrous cycle was found to be the most effective dose for induction of superovulation. Accordingly, in subsequent experiments, the dose of $200 \mu \mathrm{l}$ inhibin antiserum was used to induce (super)ovulation in mice. Injections of inhibin antiserum (treated group) or $100 \mu$ l goat serum (control group) were administered i.p. at 12:00 h on each day of the 4 day oestrous cycle. The rest of the protocol was similar to that used in Expt 1.

\section{Experiment 3: effect of different doses of inhibin antiserum on oocyte production, fertilization and embryo development in immature mice}

Female mice aged 26 days were treated using the same protocol as that used in Expt 1. Doses ranging from $50 \mu \mathrm{l}$ to 
Table 1. Effect of inhibin antiserum or equine chorionic gonadotrophin (eCG), administered i.p. to adult mice on day 2 of the oestrous cycle (day 1 of dioestrus), on the number of ovulating mice and the number of ovulated oocytes per animal

\begin{tabular}{lcc}
\hline Treatment & Number of mice that ovulated & Number of ovulated oocytes (range) \\
\hline Control serum & $5 / 5$ & $18.0 \pm 0.8(15-20)$ \\
$50 \mu \mathrm{l}$ inhibin antiserum & $5 / 5$ & $44.2 \pm 7.1(26-66)^{*}$ \\
$100 \mu \mathrm{l}$ inhibin antiserum & $5 / 5$ & $59.0 \pm 4.9(48-77)^{* * *}$ \\
$200 \mu \mathrm{l}$ inhibin antiserum & $5 / 5$ & $73.0 \pm 7.4(60-94)^{* * * a}$ \\
$400 \mu \mathrm{l}$ inhibin antiserum & $5 / 5$ & $63.2 \pm 4.9(52-80)^{* * * a}$ \\
10 iu eCG & $5 / 5$ & $37.4 \pm 3.1(31-47)^{* * *}$ \\
20 iu eCG & $5 / 5$ & $41.6 \pm 3.4(30-49)^{* * *}$ \\
\hline
\end{tabular}

Values are mean $\pm \operatorname{SEM}(n=5)$.

${ }^{*} P<0.05$ and ${ }^{* * *} P<0.005$ versus control group that received goat serum.

a $P<0.05$ versus eCG-treated groups.

$400 \mu \mathrm{l}$ inhibin antiserum (treated group) were used to induce superovulation, whereas the animals in the control group received $100 \mu \mathrm{l}$ goat serum.

\section{Embryo collection and culture in vitro}

At 06:00 h on day 2 after mating, fertilized (two-cell stage embryos) oocytes and also unfertilized and degenerated oocytes were harvested by flushing the excised oviducts with embryo culture medium-KSOM solution (containing $\mathrm{NaCl}$ $\left(5.55 \mathrm{~g} \mathrm{l}^{-1}\right), \quad \mathrm{KCl}\left(0.185 \mathrm{gl}^{-1}\right)$, glucose $\left(1 \mathrm{gl}^{-1}\right), \mathrm{KH}_{2} \mathrm{PO}_{4}$ $\left(0.047 \mathrm{~g} \mathrm{l}^{-1}\right), \mathrm{MgSO}_{4}\left(0.024 \mathrm{~g} \mathrm{l}^{-1}\right)$, lactate $(1.88 \mathrm{ml})$, pyruvate $\left(0.022 \mathrm{~g} \mathrm{l}^{-1}\right), \mathrm{NaHCO}_{3}\left(2.1 \mathrm{~g} \mathrm{l}^{-1}\right), \mathrm{CaCl}_{2} \cdot 2 \mathrm{H}_{2} \mathrm{O}\left(0.25 \mathrm{~g} \mathrm{I}^{-1}\right)$, L-glutamine $\left(0.146 \mathrm{~g}^{-1}\right)$, EDTA $\left(0.0029 \mathrm{~g}^{-1}\right)$, penicillinstreptomycin (0.075 and $0.050 \mathrm{~g} \mathrm{I}^{-1}$, respectively)) with $0.5 \%(\mathrm{w} / \mathrm{v})$ BSA (Fraction V; Sigma Co., St Louis, MO) (Ho et al., 1995; Summers et al., 1995). The numbers of fertilized and unfertilized oocytes were recorded to evaluate the rates of oocyte production and fertilization. The two-cell stage embryos were harvested and cultured at $37^{\circ} \mathrm{C}$ in fresh KSOM solution in $5 \% \mathrm{CO}_{2}$ in air, 95\% relative humidity for $54 \mathrm{~h}$ (96 h after hCG administration). The hatched blastocysts were counted at the end of the culture period.

\section{Statistical analysis}

Data are presented as mean \pm SEM. Significance of differences between two means was tested by Student's $t$ test if the variance was uniform or by Cochran-Cox test if the variance was not uniform. The level of significance was $P<0.05$.

\section{Results}

Experiment 1: effect of different doses of inhibin antiserum administered on day 2 of the oestrous cycle on oocyte production, fertilization and embryo development in cyclic mice

All the mice tested in each experimental group were superovulated (Table 1). Administration of various doses of inhibin antiserum (50-400 $\mu \mathrm{l}$ per animal) or eCG (10 or
20 iu per animal) at 12:00 h on day 2 of the oestrous cycle significantly $(P<0.05)$ increased the number of ovulations compared with that in the control group treated with goat serum (Table 1). The most effective dose to induce superovulation was $200 \mu \mathrm{l}$ inhibin antiserum. The oocyte production in mice treated with $200 \mu \mathrm{l}$ or $400 \mu \mathrm{l}$ inhibin antiserum was also significantly $(P<0.05)$ higher than that in the two groups of eCG-treated mice.

The number of two-cell stage embryos and the rate of fertilization for each treatment group are shown (Table 2). The early embryos were harvested by flushing the excised oviducts with KSOM solution at day 2 after mating. The production of two-cell stage embryos in the groups treated with either inhibin antiserum or eCG was significantly $(P<0.05)$ higher than that of the control group (Table 2$)$. The number of two-cell stage in the group treated with $200 \mu \mathrm{l}$ inhibin antiserum was significantly $(P<0.005)$ higher than in either eCG-treated group. However, the rate of fertilization was not different between the inhibin antiserum- or eCG-treated groups and the control group (Table 2).

The effects of inhibin antiserum and eCG on development of hatched blastocysts are shown (Table 2). The number of hatched blastocysts for the groups treated with either inhibin antiserum or eCG was significantly $(P<0.05)$ higher than in the control group (Table 2$)$. Furthermore, there was no difference in the rate of blastocyst development between groups treated with 50, 100 or $200 \mu \mathrm{l}$ inhibin antiserum and the control group. The rates of blastocyst development in the groups treated with 50, 100 or $200 \mu \mathrm{l}$ inhibin antiserum were significantly $(P<0.05)$ higher than those in both of the eCG-treated groups (10 or $20 \mathrm{iu}$ ) (Table 2).

\section{Experiment 2: effect of a single injection of $200 \mu \mathrm{l}$ inhibin antiserum administered on each of 4 days of the oestrous cycle on oocyte production, fertilization and embryo development}

When mice were treated with $200 \mu$ inhibin antiserum on each day of the oestrous cycle, all the animals were 
Table 2. Effect of inhibin antiserum or equine chorionic gonadotrophin (eCG), administered i.p. on day 2 of the oestrous cycle (day 1 of dioestrus), on production of fertilized oocytes (two-cell stage embryos), rate of fertilization in vivo, production of hatched blastocysts and rate of blastocyst development in adult mice

\begin{tabular}{lllll}
\hline Treatment & $\begin{array}{c}\text { Number of fertilized } \\
\text { oocytes (range) }\end{array}$ & $\begin{array}{c}\text { Fertilization } \\
\text { rate }(\%)\end{array}$ & $\begin{array}{c}\text { Number of hatched } \\
\text { blastocysts (range) }\end{array}$ & $\begin{array}{c}\text { Rate of blastocyst } \\
\text { development }(\%)\end{array}$ \\
\hline Control serum & $15.2 \pm 0.7(13-17)$ & $84.6 \pm 1.6$ & $13.8 \pm 0.5(12-15)$ & $90.9 \pm 1.3$ \\
$50 \mu$ inhibin antiserum & $35.2 \pm 5.2(21-47)^{*}$ & $80.2 \pm 2.8$ & $30.6 \pm 4.7(19-42)^{*}$ & $86.9 \pm 1.5^{\mathrm{b}}$ \\
$100 \mu$ l inhibin antiserum & $49.6 \pm 4.8(37-63)^{* * *}$ & $83.9 \pm 3.7$ & $42.6 \pm 3.6(33-54)^{* * * a}$ & $86.4 \pm 1.7^{\mathrm{a}}$ \\
$200 \mu \mathrm{l}$ inhibin antiserum & $60.2 \pm 3.7(52-72)^{* * * b}$ & $83.9 \pm 4.2$ & $53.0 \pm 4.3(41-67)^{* * * b}$ & $87.7 \pm 2.4^{\mathrm{a}}$ \\
$400 \mu \mathrm{l}$ inhibin antiserum & $48.4 \pm 6.2(29-62)^{* *}$ & $75.6 \pm 5.8$ & $39.2 \pm 5.8(21-52)^{*}$ & $80.0 \pm 2.4^{* * *}$ \\
10 iu eCG & $29.0 \pm 1.4(25-32)^{* * *}$ & $78.6 \pm 3.9$ & $21.2 \pm 1.0(19-24)^{* * *}$ & $73.2 \pm 2.2^{* * *}$ \\
20 iu eCG & $32.8 \pm 2.6(26-41)^{* * *}$ & $79.3 \pm 6.6$ & $22.0 \pm 2.1(17-27)^{* *}$ & $67.2 \pm 4.1^{* *}$ \\
\hline
\end{tabular}

Values are mean $\pm \operatorname{SEM}(n=5)$.

$* P<0.05,{ }^{* *} P<0.01$ and ${ }^{* * *} P<0.005$ versus control group that received goat serum.

a $P<0.05$ and ${ }^{b} P<0.005$ versus eCG-treated groups.

Table 3. Effect of $200 \mu$ inhibin antiserum, administered i.p. into adult mice on each day of a 4 day oestrous cycle, on the number of ovulating mice and the number of ovulated oocytes per animal

\begin{tabular}{|c|c|c|c|}
\hline Stage of oestrous cycle & Treatment & $\begin{array}{c}\text { Number of mice that } \\
\text { ovulated }\end{array}$ & $\begin{array}{l}\text { Number of ovulated } \\
\text { oocytes (range) }\end{array}$ \\
\hline \multirow[t]{2}{*}{ Day 1 of oestrous cycle (oestrus) } & Control serum & $5 / 5$ & $13.8 \pm 2.2(8-20)$ \\
\hline & $200 \mu \mathrm{l}$ inhibin antiserum & $5 / 5$ & $63.4 \pm 5.4(49-78)^{* * *}$ \\
\hline \multirow[t]{2}{*}{ Day 2 of oestrous cycle (day 1 of dioestrus) } & Control serum & $5 / 5$ & $18.0 \pm 0.8(15-20)$ \\
\hline & $200 \mu \mathrm{l}$ inhibin antiserum & $5 / 5$ & $73.0 \pm 7.4(60-94)^{* * *}$ \\
\hline \multirow[t]{2}{*}{ Day 3 of oestrous cycle (day 2 of dioestrus) } & Control serum & $5 / 5$ & $14.2 \pm 0.6(13-16)$ \\
\hline & $200 \mu \mathrm{l}$ inhibin antiserum & $5 / 5$ & $66.2 \pm 8.2(41-91)^{* * *}$ \\
\hline \multirow[t]{2}{*}{ Day 4 of oestrous cycle (pro-oestrus) } & Control serum & $4 / 5$ & $12.0 \pm 2.0(0-16)$ \\
\hline & $200 \mu \mathrm{l}$ inhibin antiserum & $5 / 5$ & $48.4 \pm 7.0(33-74)^{*}$ \\
\hline
\end{tabular}

Values are mean $\pm \operatorname{SEM}(n=5)$.

$* P<0.05$ and ${ }^{* * *} P<0.005$ versus corresponding control group that received goat serum.

superovulated (Table 3). The rates of oocyte and embryo production were significantly $(P<0.05)$ higher in the inhibin antiserum-treated animals than in the control animals (Tables 3 and 4). However, the rates of oocyte and embryo production were not different among groups treated with inhibin antiserum at 12:00 $\mathrm{h}$ on different days of the oestrous cycle.

\section{Experiment 3: effect of different doses of inhibin antiserum on oocyte production, fertilization and embryo development in immature mice}

All the animals tested in each experimental group were superovulated (Table 5). Administration of various doses of inhibin antiserum (50-400 $\mu \mathrm{l}$ per animal) significantly $(P<0.01)$ increased oocyte production compared with that in the control group (Table 5). The number of two-cell stage embryos in the inhibin antiserum-treated animals was significantly $(P<0.005)$ higher than that for the control group (Table 5). However, the rate of fertilization was not different between the inhibin antiserum-treated groups and the control group (Table 6). Owing to significant differences in production of two-cell stage embryos between the inhibin antiserum-treated groups and the control group, the number of hatched blastocysts for each of the inhibin antiserumtreated groups was significantly $(P<0.01)$ higher than that for the control group (Table 6). There was no difference in rates of blastocyst development among different treatments (Table 6).

\section{Discussion}

Many studies involving superovulation have been conducted in mice (Christenson and Eleftheriou, 1972; Spindle and Goldstein, 1975; Cosby et al., 1989; Garcia et al., 1993; Ziebe et al., 1993; Munoz et al., 1995). In these studies, an eCG-hCG protocol has been used because this combination can produce a relatively large number of ovulations. However, preimplantation embryo development and successful implantation of superovulated oocytes induced by eCG-hCG appear to be interfered with by high concentrations of oestradiol, probably because of longlasting high circulating concentrations of eCG (Fraser, 
Table 4. Effect of $200 \mu \mathrm{l}$ inhibin antiserum, administered i.p. into adult mice on each day of a 4 day oestrous cycle, on production of fertilized oocytes (two-cell stage embryos), rate of fertilization in vivo, production of hatched blastocysts and rate of blastocyst development

\begin{tabular}{|c|c|c|c|c|c|}
\hline $\begin{array}{l}\text { Stage of } \\
\text { oestrous cycle }\end{array}$ & Treatment & $\begin{array}{l}\text { Number of fertilized } \\
\text { oocytes (range) }\end{array}$ & $\begin{array}{l}\text { Fertilization } \\
\text { rate }(\%)\end{array}$ & $\begin{array}{l}\text { Number of hatched } \\
\text { blastocysts (range) }\end{array}$ & $\begin{array}{l}\text { Rate of blastocyst } \\
\text { development (\%) }\end{array}$ \\
\hline \multirow{2}{*}{$\begin{array}{l}\text { Day } 1 \text { of oestrous cycle } \\
\text { (oestrus ) }\end{array}$} & Control serum & $11.8 \pm 2.2(6-18)$ & $83.8 \pm 0.3$ & $10.2 \pm 2.0(5-16)$ & $85.9 \pm 1.1$ \\
\hline & $200 \mu \mathrm{l}$ inhibin antiserum & $53.6 \pm 5.0(37-64)^{* * *}$ & $84.4 \pm 3.2$ & $44.2 \pm 5.9(26-59)^{* * *}$ & $81.3 \pm 4.3$ \\
\hline \multirow{2}{*}{$\begin{array}{l}\text { Day } 2 \text { of oestrous cycle } \\
\text { (day } 1 \text { of dioestrus) }\end{array}$} & Control serum & $15.2 \pm 0.7(13-17)$ & $84.6 \pm 1.6$ & $13.8 \pm 0.5(12-15)$ & $90.9 \pm 1.3$ \\
\hline & $200 \mu \mathrm{l}$ inhibin antiserum & $60.2 \pm 3.7(52-72)^{* * *}$ & $83.9 \pm 4.2$ & $53.0 \pm 4.3(41-67)^{* * *}$ & $87.7 \pm 2.4$ \\
\hline \multirow{2}{*}{$\begin{array}{l}\text { Day } 3 \text { of oestrous cycle } \\
\text { (day } 2 \text { of dioestrus) }\end{array}$} & Control serum & $12.4 \pm 0.2(12-13)$ & $87.6 \pm 0.2$ & $10.2 \pm 0.4(9-11)$ & $82.2 \pm 1.8$ \\
\hline & $200 \mu \mathrm{l}$ inhibin antiserum & $54.6 \pm 8.0(31-74)^{* *}$ & $81.6 \pm 8.9$ & $45.2 \pm 7.9(21-61)^{*}$ & $81.1 \pm 4.1$ \\
\hline \multirow{2}{*}{$\begin{array}{l}\text { Day } 4 \text { of oestrous cycle } \\
\text { (pro-oestrus) }\end{array}$} & Control serum & $10.5 \pm 1.8(6-14)$ & $87.0 \pm 4.6$ & $9.3 \pm 1.7(5-12)$ & $87.6 \pm 1.9$ \\
\hline & $200 \mu \mathrm{l}$ inhibin antiserum & $43.0 \pm 6.7(30-68)^{*}$ & $88.5 \pm 3.2$ & $37.6 \pm 6.0(26-60)^{*}$ & $87.2 \pm 0.1$ \\
\hline
\end{tabular}

Values are mean $\pm \operatorname{SEM}(n=5)$.

${ }^{*} P<0.05,{ }^{* *} P<0.01$ and ${ }^{* * *} P<0.005$ versus corresponding control group that received goat serum.

Table 5. Effect of inhibin antiserum, administered i.p. into 26-day-old immature mice, on the number of ovulating mice and the number of ovulated oocytes per animal

\begin{tabular}{lcc}
\hline Treatment & Number of mice that ovulated & Number of ovulated oocytes (range) \\
\hline Control serum & $5 / 5$ & $14.4 \pm 1.1(11-17)$ \\
$50 \mu$ l inhibin antiserum & $5 / 5$ & $67.8 \pm 8.2(44-89)^{* * *}$ \\
$100 \mu$ inhibin antiserum & $5 / 5$ & $87.4 \pm 10.9(72-101)^{* * *}$ \\
$200 \mu$ inhibin antiserum & $5 / 5$ & $102.8 \pm 9.8(81-137)^{* * *}$ \\
$400 \mu$ inhibin antiserum & $5 / 5$ & $67.4 \pm 11.2(47-109)^{* *}$ \\
\hline
\end{tabular}

Values are mean $\pm \operatorname{SEM}(n=5)$.

${ }^{* *} P<0.01$ and ${ }^{* * *} P<0.005$ versus control group that received goat serum.

Table 6. Effect of inhibin antiserum, administered i.p. into 26-day-old immature mice, on production of fertilized oocytes (two-cell stage embryos), rate of fertilization in vivo, production of hatched blastocysts and rate of blastocyst development

\begin{tabular}{lllll}
\hline Treatment & $\begin{array}{c}\text { Number of fertilized } \\
\text { oocytes (range) }\end{array}$ & $\begin{array}{c}\text { Fertilization } \\
\text { rate }(\%)\end{array}$ & $\begin{array}{c}\text { Number of hatched } \\
\text { blastocysts (range) }\end{array}$ & $\begin{array}{c}\text { Rate of blastocyst } \\
\text { development }(\%)\end{array}$ \\
\hline Control serum & $11.8 \pm 1.0(9-14)$ & $81.8 \pm 1.6$ & $10.2 \pm 0.7(8-12)$ & $86.8 \pm 1.1$ \\
$50 \mu$ inhibin antiserum & $55.0 \pm 6.3(36-71)^{* * *}$ & $81.4 \pm 0.8$ & $47.4 \pm 5.2(32-61)^{* * *}$ & $86.4 \pm 1.1$ \\
$100 \mu \mathrm{l}$ inhibin antiserum & $72.8 \pm 4.1(59-84)^{* * *}$ & $83.3 \pm 0.6$ & $63.2 \pm 4.0(52-74)^{* * *}$ & $86.7 \pm 1.7$ \\
$200 \mu \mathrm{l}$ inhibin antiserum & $86.0 \pm 7.5(68-112)^{* * *}$ & $83.9 \pm 1.0$ & $73.4 \pm 5.3(60-91)^{* * *}$ & $85.7 \pm 1.2$ \\
$400 \mu$ inhibin antiserum & $51.6 \pm 7.3(36-78)^{* * *}$ & $77.6 \pm 2.0$ & $43.2 \pm 6.3(30-66)^{* *}$ & $83.5 \pm 0.7$ \\
\hline
\end{tabular}

Values are mean $\pm \operatorname{SEM}(n=5)$.

${ }^{* *} P<0.01$ and ${ }^{* * *} P<0.005$ versus control group that received goat serum.

1977; Sato and Marrs, 1986; Edgar et al., 1987; Lehtonen and Kankondi, 1987; Fossum et al., 1989; Ertzeid et al., 1993; Legge and Sellens, 1994; Ma et al., 1997). This possibility led us to consider an alternative method that could be used to induce superovulation and to obtain a population of oocytes with high rates of successful fertilization and embryo development. Thus, the aim of the present study was to develop a new superovulation protocol in mice using immunoneutralization of endogenous inhibin. This is the first report to show that passive immunization against the inhibin $\alpha$-subunit increases the number of oocytes and rate of blastocyst production in both immature and adult mice.

The mice that received 50-400 $\mu$ inhibin antiserum on day 1 of dioestrus (day 2 of oestrus) were superovulated. The production of oocytes by the mice treated with the inhibin antiserum protocol increased markedly in a dosedependent manner. Fifty microlitres of inhibin antiserum was sufficient to induce superovulation, whereas $200 \mu \mathrm{l}$ inhibin antiserum was the most effective dose. Inhibin antiserum did not have any adverse effects on embryo quality as assessed by morphological and developmental 
competence in mice. The superovulated oocytes could be fertilized normally in vivo, leading to the development of blastocysts in the same chronological progression as observed in vitro after normal ovulation of oocytes. Furthermore, as immature mice are used widely to obtain mature oocytes or embryos, similar experiments were conducted using 26-day-old mice. The data obtained with immature mice in the present study were comparable, in terms of both differences among doses and among different treatment groups, to those of adult mice. Many previous studies have shown that FSH plays a major role in the regulation of ovarian folliculogenesis. In several mammalian species, inhibin is an important negative feedback regulatory factor in determining the circulating concentration of FSH (Taya, 1993; Taya and Watanabe, 1999). Suppression of negative feedback of inhibin upon the pituitary gonadotrophs increases FSH secretion (Ireland et al, 1983; Quirk and Fortune, 1986; Beard et al., 1990). In previous studies, it has been reported that passive immunization against inhibin increased the circulating FSH concentrations in rats (Rivier and Vale, 1989; Arai et al., 1996), hamsters (Kishi et al., 1996), guinea-pigs (Shi et al., 1999), cows (Taya et al., 1991; Kaneko et al., 1993), ewes (Wheaton et al., 1992; Wrathall et al., 1992) and mares (Nambo et al., 1998). However, the results of the present study do not provide direct evidence as to whether the improvement in oocyte production observed in mice immunized against inhibin $\alpha$ subunit is due to increases in plasma FSH concentrations. Anti-inhibin IgG is able to enter the follicular fluid of antral follicles after passive immunization, indicating that inhibin antibodies play a local role affecting follicular development (Shi et al., 2000). As plasma FSH concentrations were not measured in the present study, further studies are needed to elucidate the mechanism by which immunoneutralization of endogenous inhibin increases oocyte production in both immature and adult mice.

The results of the present study demonstrate that 26-dayold immature mice appear to be more responsive to inhibin antiserum than do adult mice. All the doses of inhibin antiserum tested stimulated a relatively higher number of follicles to develop in vivo and subsequently to be ovulated in immature mice compared with adult mice. This finding indicates that immature mice aged at least 26 days have acquired a functional negative feedback control of pituitary FSH secretion by ovarian inhibin. A different responsiveness observed between cyclic and immature animals in response to the inhibin antiserum may be explained, at least in part, by differences in the concentrations of other negative regulatory factors of gonadotrophin secretion, such as oestradiol. In addition, Spearow et al. (1999) reported that several genes, such as Oriq, determine the ovulation rate. The expression of these genes is related to ovarian responsiveness to the gonadotrophins. Therefore, it is possible that the expression of these genes varies during development from the immature to the adult stage. However, it has not yet been determined whether the inhibin antiserum-hCG protocol is effective in other strains of mice that are known to be poor responders to eCG-hCG treatment.

In the present study, eCG-hCG treatment increased oocyte and embryo production in adult mice of the $\mathrm{dd} Y$ strain. The fertilization of oocytes appeared to be normal; however, the rate of blastocyst formation in vitro of the oocytes obtained from eCG-hCG-treated animals was significantly decreased compared with that of mice undergoing normal ovulation and mice undergoing superovulation after treatment with 50-200 $\mu \mathrm{l}$ inhibin antiserum. Furthermore, as the dose of eCG increased, the blastocyst developmental competence of the eggs tended to be affected more markedly. The results of the present study confirm that a high dose of eCG tends to increase the number of abnormal oocytes and embryos, as has been reported in many previous studies (Fraser, 1977; Sato and Marrs, 1986; Edgar et al., 1987; Lehtonen and Kankondi, 1987; Fossum et al., 1989; Ertzeid et al., 1993). Therefore, use of the inhibin antiserum method for induction of superovulation in mice appears to be more advantageous in terms of both oocyte and embryo production and quality.

All the mice treated with $200 \mu$ inhibin antiserum on each day of the oestrous cycle were superovulated. In mice with 4 day oestrous cycles, an LH surge occurs in the afternoon of pro-oestrus (day 4 of the oestrous cycle) and subsequent ovulation takes place in the early morning of oestrus (day 1) (Parkening et al., 1982). When the inhibin antiserum protocol was performed chronologically as described earlier, higher numbers of oocytes and embryos were obtained. When $200 \mu \mathrm{l}$ inhibin antiserum was administered to ddY mice on days 1, 3 or 4 of oestrus (day of oestrus, day 2 of dioestrus or day of pro-oestrus, respectively), the rates of oocyte and embryo production were decreased compared with mice that received inhibin antiserum on day 2 of oestrus (day 1 of dioestrus). However, the ovulation rate for these mice was still significantly higher than that of the control mice. Kishi et al. (1996) reported that inhibin antiserum administered on day 1, 2 or 3 of the oestrous cycle (oestrus, day 1 or 2 of dioestrus) increased the rate of ovulation in hamsters significantly. Superovulation could also be induced by administration of exogenous gonadotrophin on random days of the oestrous cycle in mice (Fowler and Edwards, 1957; Edwards and Fowler, 1960; Redina et al., 1994). Thus, it seems that the inhibin antiserum-hCG protocol works in line with other protocols that are commonly used for the induction of superovulation, but that the inhibin antiserum protocol yields superior results in mice. Slight differences in oocyte and embryo production in response to administration of inhibin antiserum on different days of the oestrous cycle may be due to a different follicular population in the ovary at different stages of the cycle.

In conclusion, passive immunization against endogenous inhibin $\alpha$-subunit induces superovulation in immature and adult mice. The superovulated oocytes have normal embryonic developmental competence in vitro. As it is relatively easy to obtain inhibin antiserum in large volumes 
at a low cost through immunization of goats against inhibin $\alpha$-subunit, the inhibin antiserum-hCG method is an ideal alternative for induction of superovulation in mice compared with the more commonly used eCG-hCG protocol.

The authors would like to thank S. K. Dey (Department of Pediatrics, Ralph L. Smith Research Center, University of Kansas Medical Center, Kansas City, KS) for his valuable suggestions. The authors are grateful to N. Ling (Neurocrine Biosciences Inc., San Diego, CA) for providing $\left[\mathrm{Tyr}^{30}\right]$-porcine inhibin- $\alpha(1-30)-\mathrm{NH}_{2} . \mathrm{H}$. Wang received a short-term Student Exchange Promotion Program (Inbound) Scholarship from the Association of International Education of Japan (AIEJ). This work was supported in part by US-Japan Cooperative Research Grant from the Japan Society for the Promotion of Science.

\section{References}

Akagi S, Kaneko H, Nakanishi Y, Takedomi T, Watanabe G and Taya K (1997) Ovarian response and FSH profile in cows following injection of various doses of inhibin antiserum Journal of Veterinary Medical Science 59 1129-1135

Arai K, Watanabe G, Taya K and Sasamoto S (1996) Roles of inhibin and estradiol in the regulation of follicle-stimulating hormone and luteinizing hormone secretion during the estrous cycle of the rat Biology of Reproduction 55 127-133

Beard AJ, Castillo RJ, McLeod BJ, Glencross RG and Knight PG (1990) Comparison of the effects of crude and highly purified bovine inhibin (Mr 32,000) on plasma concentrations of FSH and $\mathrm{LH}$ in chronically ovariectomized prepubertal heifers Journal of Endocrinology 125 21-30

Christenson CM and Eleftheriou BE (1972) Dose-dependence of superovulation response in mice to two injections of PMSG Journal of Reproduction and Fertility 29 287-289

Cosby NC, Chou K and Dukelow WR (1989) Embryo production in B6D2F1 mice using two superovulating regimens Laboratory Animal Science $39249-250$

de Jong FH (1988) Inhibin Physiological Reviews 68 555-607

Edgar DH, Whalley KM and Millis JA (1987) Effects of high-dose and multiple-dose gonadotropin stimulation on mouse oocyte quality as assessed by preimplantation development following in vitro fertilization Journal of In Vitro Fertilization and Embryo Transfer 4 273-276

Edwards RG and Fowler RE (1960) Superovulation treatment of adult mice: their subsequent natural fertility and response to further treatment Journal of Endocrinology 21 147-154

Ertzeid G, Storeng R and Lyberg T (1993) Treatment with gonadotropins impaired implantation and fetal development in mice Journal of Assisted Reproduction and Genetics 10 286-291

Fossum GT, Davidson A and Paulson RJ (1989) Ovarian hyperstimulation inhibits embryo implantation in the mouse Journal of In Vitro Fertilization and Embryo Transfer 6 7-10

Fowler RE and Edwards RG (1957) Induction of superovulation and pregnancy in mature mice by gonadotropin Journal of Endocrinology $\mathbf{1 5}$ 374-384

Fraser LR (1977) Fertilization and preimplantation development in vitro of mouse eggs obtained following stimulation with different doses of pregnant mare serum: a comparison of the responses in two strains Differentiation 9 29-35

Garcia J, Kholkute SD and Dukelow WR (1993) The efficacy of stored pregnant mares serum gonadotropin and human chorionic gonadotropin on inducing ovulation in mice Laboratory Animal Science 43 198-199

Ho Y, Wigglesworth K, Eppig JJ and Schultz RM (1995) Preimplantation development of mouse embryos in KSOM: augmentation by amino acids and analysis of gene expression Molecular Reproduction and Development 941 232-238

Ireland JJ, Curato AD and Wilson J (1983) Effect of charcoal-treated bovine follicular fluid on secretion of $\mathrm{LH}$ and $\mathrm{FSH}$ in ovariectomized heifers Journal of Animal Science 57 1512-1516

Kaneko H, Nakanishi Y, Taya K, Kishi H, Watanabe G, Sasamoto S and Hasegawa $\mathbf{Y}$ (1993) Evidence that inhibin is an important factor in the regulation of FSH secretion during the mid-luteal phase in cows Journal of Endocrinology 136 35-41

Kishi H, Okada T, Otsuka M, Watanabe G, Taya K and Sasamoto S (1996) Induction of superovulation by immunoneutralization of endogenous inhibin through the increase in the secretion of follicle stimulating hormone in the cyclic golden hamster Journal of Endocrinology $\mathbf{1 5 1}$ 65-75

Legge $\mathbf{M}$ and Sellens $\mathbf{M H}$ (1994) Optimization of superovulation in the reproductively mature mouse Journal of Assisted Reproduction and Genetics 11 312-318

Lehtonen E and Kankondi R (1987) Rate of gonadotrophin-induced abnormalities in mouse ova is related to the site of hormone administration Journal of Reproduction and Fertility 80 613-617

Ma S, Kalousek DK, Yuen BH and Moon YS (1997) Investigation of effects of pregnant mare serum gonadotropin (PMSG) on the chromosomal complement of CD-1 mouse embryos Journal of Assisted Reproduction and Genetics 14 162-169

Munoz I, del Nino JA, Josa A, Espinosa E and Gil I (1995) Use of folliclestimulating hormone (FSH) to increase the in vitro fertilization (IVF) efficiency of mice Journal of Assisted Reproduction and Genetics 12 738-743

Nambo Y, Kaneko H, Nagata S, Oikawa M, Yoshihara T, Nagamine N, Watanabe G and Taya K (1998) Effect of passive immunization against inhibin on FSH secretion, folliculogenesis and ovulation rate during the follicular phase of the estrous cycle in mares Theriogenology $\mathbf{5 0}$ 545-557

Parkening TA, Collins TJ and Smith ER (1982) Plasma and pituitary concentrations of $\mathrm{LH}, \mathrm{FSH}$, and prolactin in aging $\mathrm{C} 57 \mathrm{BL} / 6$ mice at various times of the estrous cycle Neurobiological Aging 331-35

Quirk SM and Fortune JE (1986) Plasma concentrations of gonadotrophins, preovulatory follicular development and luteal function associated with bovine follicular fluid-induced delay of oestrus in heifers Journal of Reproduction and Fertility $\mathbf{7 6} 6$ 609-621

Redina OE, Amstislavsky SY and Maksimovsky LF (1994) Induction of superovulation in DD mice at different stages of the oestrous cycle Journal of Reproduction and Fertility 102 263-267

Rivier C and Vale W (1989) Immunization of endogenous inhibin modifies hormone secretion and ovulation rate in the rat Endocrinology 125 $152-157$

Sato F and Marrs RP (1986) The effect of pregnant mare serum gonadotropin on mouse embryos fertilized in vivo or in vitro. Journal of In Vitro Fertilization and Embryo Transfer 6 353-357

Scott LF, Sundaram SG and Smith S (1993) The relevance and use of mouse embryo bioassays for quality control in an assisted reproductive technology program Fertility and Sterility $60559-568$

Shi F, Ozawa M, Komura H, Yang P, Trewin AL, Hutz RJ, Watanabe G and Taya K (1999) Secretion of ovarian inhibin and its physiologic roles in the regulation of follicle-stimulating hormone secretion during the estrous cycle of the female guinea pig Biology of Reproduction $\mathbf{6 0}$ 78-84

Shi F, Mochida K, Suzuki O, Mateuda J, Ogura A, Ozawa M, Watanabe G, Suzuki A and Taya K (2000) Ovarian localization of immunoglobulin G and inhibin $\alpha$-subunit in guinea pigs after passive immunization against the inhibin $\alpha$-subunit Journal of Reproduction and Development $\mathbf{4 6}$ 293-299

Spearow JL, Nutson PA, Mailliard WS, Porter M and Barkley M (1999) Mapping genes that control hormone-induced ovulation rate in mice Biology of Reproduction 61 857-872

Spindle Al and Goldstein LS (1975) Induced ovulation in mature mice and developmental capacity of the embryos in vitro. Journal of Reproduction and Fertility $\mathbf{4 4} 113-116$

Summers MC, Bhatnagar PR, Lawitts JA and Biggers JD (1995) Fertilization in vitro of mouse ova from inbred and outbred strains: complete preimplantation embryo development in glucose-supplemented KSOM Biology of Reproduction 53 431-437 
Taya K (1993) Role of inhibin in regulation of FSH secretion and folliculogenesis in mammalians Current Trends in Experimental Endocrinology 1 97-116

Taya K and Watanabe G (1999) Inhibin as a key hormone in determining species-specific ovulation rates in mammal. In Recent Progress in Molecular and Comparative Endocrinology Eds HB Kwon, JMP Joss and S Ishii pp 134-143. Hormone Research Center, Chonman National University, Kwangju

Taya K, Kaneko H, Watanabe G and Sasamoto S (1991) Inhibin and secretion of FSH in oestrous cycles of cows and pigs Journal of Reproduction and Fertility Supplement 43 151-162

Wheaton JE, Carlson KM and Kusina NT (1992) Active and passive immunoneutralization of inhibin increases follicle-stimulating hormone levels and ovulation rate in ewes Biology of Reproduction 47 361-367
Wrathall JH, McLeod BJ, Glencross RG and Knight PG (1992) Effects of active immunization against a synthetic peptide sequence of the inhibin alpha-subunit on plasma gonadotrophin concentrations, ovulation rate and lambing rate in ewes Journal of Reproduction and Fertility 95 175-182

Ziebe S, Guoliang X and Byskov AG (1993) Impact of gonadotrophin dose on pre-embryo recovery and development in superovulated mice Human Reproduction 8 385-388

Received 5 March 2001.

First decision 24 April 2001.

Accepted 9 July 2001. 